\title{
MANAJEMEN PEMELIHARAAN INDUKABALON (Haliotis asinina) HASIL TANGKAPAN DARI ALAM
}

\author{
Septyan Andriyanto dan Nurbakti Listyanto \\ Pusat Penelitian dan Pengembangan Perikanan Budidaya \\ Jl. Ragunan 20 Pasar Minggu, Jakarta Selatan 12540 \\ E-mail: septian08@ cria.indosat.net.id
}

\begin{abstract}
ABSTRAK
Abalon merupakan satu jenis kekerangan yang mempunyai nilai gizi yang cukup tinggi serta kelezatan rasanya. Usaha budidaya abalon memiliki nilai ekonomis yang tinggi, namun untuk produksinya sebagian masih mengandalkan hasil tangkapan dari alam. Dalam rangka menghasilkan induk dengan tingkat produksi yang tinggi diperlukan pengetahuan terkait manajemen pemeliharaan induk terutama yang berasal dari alam. Manajemen pemeliharaan induk yang sesuai prosedur meliputi pengumpulan induk, seleksi induk, penanganan induk, pengelolaan pakan dan penyakit, serta pengelolaan air media pemeliharaan. Apabila seluruh aspek tersebut dijalankan sesuai standar dan prosedur yang ditetapkan, diharapkan akan diperoleh induk dengan tingkat produksi yang tinggi serta benih yang berkualitas, sehingga produksi tidak selalu mengandalkan dari alam.
\end{abstract}

KATAKUNCl: abalon, induk, manajemen pemeliharaan

\section{PENDAHULUAN}

Kekerangan merupakan jenis makanan laut yang banyak digemari oleh masyarakat karena kelezatan rasanya dan kandungan gizi yang tinggi. Peningkatan jumlah penduduk dunia dan perubahan pola makan dari mengkonsumsi daging hewan darat berganti ke ikan termasuk kekerangan, mendorong manusia untuk berusaha meningkatkan produksi perikanan, baik perikanan tangkap maupun perikanan budidaya. Sampai saat ini produksi perikanan laut Indonesia (termasuk kekerangan) masih didominasi oleh hasil tangkapan alam, baik sebagai komoditas pasar lokal maupun ekspor. Kebutuhan konsumen akan produk perikanan termasuk kekerangan terus meningkat, baik kebutuhan di pasar lokal (Surabaya, Makassar, Jakarta, Medan, Batam) maupun di pasar internasional (Singapura, Hongkong, Jepang, Amerika, dan Eropa). Peningkatan permintaan pasar berarti peluang bagi pengusaha di bidang perikanan untuk mengembangkan usahanya (Setyono, 2006). Pada tahun 1990 abalon diekspor dalam bentuk kering, asin maupun dalam air garam yaitu dari Sulawesi Selatan sejumlah $31.621 \mathrm{~kg}$ dengan negara tujuan Jepang, Hongkong, dan Singapura (Direktorat Jenderal Perikanan, 1991 dalam Setiawati et al., 1995). Permintaan abalon jenis Haliotis asinina cukup banyak, terutama dari Jepang dan Hong Kong, mencapai $300 \mathrm{~kg}$ setiap dua minggu (Sarifin dalam http:// www.antaramataram.com/berita).

Luas perairan laut Indonesia mencapai 8,36 juta ha yang secara indikatif dapat dimanfaatkan untuk pengembangan kawasan budidaya laut. Dari luasan tersebut, untuk budidaya ikan bersirip (fin fish) $20 \%$ kekerangan $10 \%$ rumput laut $60 \%$ dan lainnya $10 \%$ Tingkat pemanfaatan sebagian provinsi baru mencapai kurang dari $1 \%$ namun sebagian lainnya telah mencapai di atas $1 \%$ sampai $25 \%$ yaitu DKI Jakarta sekitar $24 \%$ Bali sekitar $8 \%$ Sulawesi Tenggara sekitar 6\% dan NTT sekitar 2\% (Ditjenkanbud, 2004 dalam http://www.abalon.net/ guide). Harga abalon cukup tinggi mencapai Rp 400.000,$/ \mathrm{kg}$, bahkan sop abalon yang dijual di restoran besar harganya mencapai Rp 600.000,-/porsi berisi dua hingga tiga ekor daging kerang tersebut (Sarifin, 2010 dalam http://www.antaramataram.com/berita).

Indonesia merupakan negara kepulauan yang memiliki perairan pantai yang cocok untuk budidaya abalon dengan suhu berada pada kisaran $20^{\circ} \mathrm{C}$ (Hayashi, 1980a dalam FAO, 2000) dan nilai kandungan oksigen terlarut (DO) pada perairan laut berkisar $\pm 7 \mathrm{mg} / \mathrm{L}$ (Efendi, 2003). Kisaran salinitas normal berkisar 33\%o 35\%o (Fallu, 1991), sedangkan nilai pH sekitar 7,0-8,5 (Novotny \& Olem, 1994 dalam Effendi, 2003). Selain itu, abalon banyak ditemui di perairan yang berarus sedang dan dengan kedalaman 0,5-1 m (Imai, 1977). Salah satunya adalah perairan pantai di Lombok yang sangat produktif dengan populasi pakan alami yang melimpah untuk budidaya abalon (seperti rumput laut jenis Gracilaria sp., Hypnea sp., Ulva sp., 
Kappaphycussp.). Berbagai metode budidaya abalon dapat diterapkan di perairan Lombok, mulai dari budidaya di darat (pembenihan), pembesaran di perairan pantai maupun di perairan dalam (Setyono, 2005).

Rusdi et al. (2009) menyatakan bahwa Indonesia hingga saat ini masih mengandalkan hasil tangkapan di alam yang produksinya cenderung terus mengalami penurunan, bahkan dilaporkan di beberapa daerah penangkapan abalon telah terjadi eksploitasi yang intensif sehingga dikhawatirkan akan mengganggu keseimbangan populasi abalon di alam yang lambat laun akan berdampak pada kepunahan.

Daging abalon mempunyai nilai gizi tinggi dengan kandungan protein $71,99 \%$ lemak $3,20 \%$ serat $5,60 \%$ dan abu 11,11\% (Sudradjat, 2008). Riset terkait budidaya abalon telah dilakukan Balai Besar Riset Perikanan Budidaya Laut, Gondol sejak tahun 2007. Produksi benih abalon secara massal telah dapat dilakukan walaupun dalam jumlah yang masih terbatas. Dengan tersedianya benih dari hatcheri memungkinkan dilakukan usaha budidaya khususnya pembesarannya (Sutarmat et al., 2009).

Pengetahuan terkait manajemen pemeliharaan induk perlu dikuasai untuk memperoleh metode pengelolaan induk sesuai standar budidaya. Manajemen pemeliharaan induk yang sesuai alur/prosedur meliputi pengumpulan induk, seleksi induk, penanganan induk, pengelolaan pakan dan penyakit, serta pengelolaan air media pemeliharaan. Seluruh aspek budidaya tersebut harus dijalankan sesuai standar dan prosedur yang telah ditetapkan agar tujuan budidaya yang aman dan lestari dapat terwujud.

\section{SEKILAS TENTANG ABALON}

Saat ini terdapat beberapa jenis abalon yang memiliki nilai ekonomis tinggi dengan harga mencapai Rp 400.000,$/ \mathrm{kg}$ dan tersebar di beberapa negara. Amerika Utara dari jenis Haliotis rufescens, H. fulgens, H. corrugata, H. sorenseni, $H$. assimilis, $H$. cracherodii, $H$. wallensis, dan $H$. kamtschatkana; Jepang dari jenis H. discus hannai, H. discus, H. Sieboldii, dan H. gigantea; Australia dari jenis H. rubra, H. laevigata, H. roci; Selandia Baru dari jenis H. iris dan H. australis; Perancis dari jenis Haliotis tuberculata; dan Afrika Selatan dari jenis Haliotis midae (Hahn, 1989b dalam Setyono, 1997). Sedangkan abalon terbesar yang ditemukan di perairan Indonesia adalah dari jenis Haliotis asinina (Dharma, 1988 dalam Setyono, 1997).

Abalon merupakan jenis moluska yang memiliki nilai fekunditas yang tinggi. Induk betina yang memiliki panjang cangkang 75-100 mm serta bobot badan 120-150 g dapat melepaskan tiga sampai enam juta telur tiap pemijahan. Sedangkan induk yang lebih besar dengan panjang cangkang $10 \mathrm{~cm}$ mampu menghasilkan lebih dari sebelas juta butir telur (Stickney, 2000).

Menurut Bilowo (1973), abalon memiliki cangkang pipih dan lonjong panjang berkisar antara 6,5-8,0 cm dan lebar berkisar 1,5-3,0 cm. Pada cangkangnya terlihat sederetan lubang-lubang kecil sebanyak tujuh buah. Lapisan dalam cangkang berwarna putih mengkilat, sedangkan otot kakinya sangat tebal yaitu kira-kira 2-2,5 cm. Ukuran badan relatif lebih besar dibandingkan cangkangnya sehingga cangkang tersebut hanya menutupi sebagian kecil organ tubuh (Gambar 1).

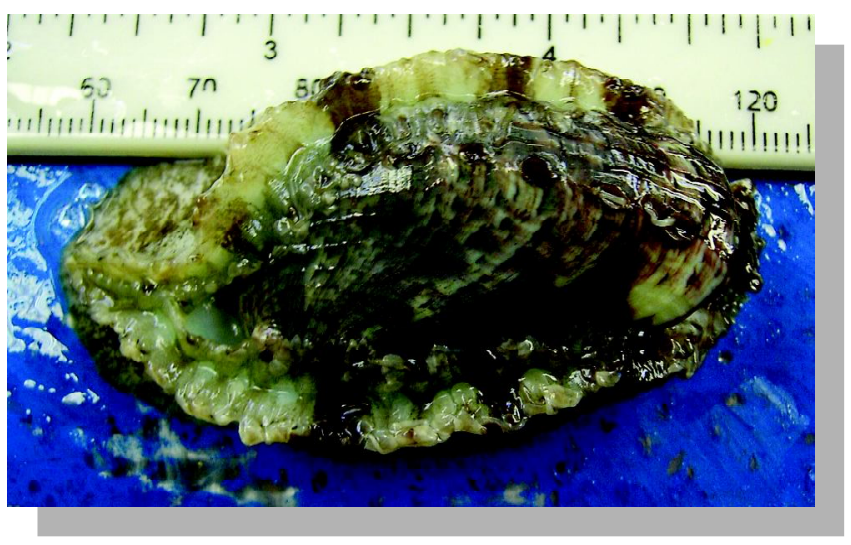

Gambar 1. Induk abalon (Haliotis asinina)

Pembukaan cangkang (Foramina) terjadi seiring bertambah besarnya ukuran cangkang dan umur. Melalui foramina terjadi beberapa aktivitas seperti pertukaran oksigen, pembuangan kotoran, karbondioksida bahkan tempat keluarnya gamet saat proses pemijahan. Anus dan ginjal terletak di bawah lubang pertama, sehingga aktivitas yang berhubungan dengan pengeluaran kotoran melalui lubang pertama. Bahkan kadangkala abalon mengeluarkan tentakelnya melalui lubang-lubang tersebut untuk membersihkan cangkangnya (Bamfield, 2005).

\section{Habitat dan Penyebaran}

Abalon muda yang berumur 1 sampai 2 tahun banyak ditemui di perairan yang berarus sedang dengan kedalaman 0,5-1 m (Imai, 1977) dan pada karang serta bebatuan (Fallu, 1991). Menurut Setiawati et al. (1995), abalon terdapat di perairan pantai berkarang di laut terbuka mulai dari tepi perairan pantai yang dangkal sampai kedalaman $20 \mathrm{~m}$. Abalon menggunakan kakinya untuk berjalan dan merayap pada permukaan karang atau bebatuan yang permukaannya kasar, sehingga spesies ini lebih banyak ditemukan dibalik karang ataupun bebatuan 
yang permukaannya kasar serta gelap. Priyambodo et al. (2005) menyatakan daerah penyebaran di perairan pantai Indonesia antara lain di Nusa Tenggara Barat (Lombok Tengah Selatan), Ambon, Madura, dan Bajo (Sulawesi Selatan).

\section{MANAJEMEN PEMELIHARAAN}

\section{Pengumpulan Induk Alam}

Berdasarkan pengamatan yang dilakukan penulis selama penelitian, pengumpulan induk dilakukan saat terjadi bulan purnama dan bulan gelap karena pada saat itu terjadi surut terendah sehingga memudahkan nelayan untuk menangkap induk. Cara penangkapan induk abalon lebih mudah ditangkap dalam keadaan istirahat, di mana nelayan akan melepas dan mengangkat dengan menggunakan alat tangkap berupa besi yang ujungnya dibuat pipih (Fallu, 1991). Nelayan di sekitar Pantai Lombok menangkap induk alam dengan cara menyelam. Metode penangkapan dilakukan dengan meletakkan besi pengait pada bagian posterior yaitu di antara cangkang dan kepala, hal ini dimaksudkan untuk mencegah terlukanya abalon dan nelayan dapat lebih mudah menangkap ketika abalon sedang bergerak.

\section{Seleksi Induk}

Seleksi induk abalon sangat menentukan tingkat keberhasilan pemijahan dan penentuan tingkat kematangan gonad dapat dilakukan dengan mengukur panjang cangkang dan dengan melihat perkembangan gonadnya. Seleksi induk dilakukan 1-2 hari sebelum pemijahan atau empat sampai lima hari menjelang bulan gelap/bulan terang untuk menghindari terjadinya pemijahan lebih awal. Induk yang diseleksi adalah induk yang memiliki cangkang utuh atau tidak retak, tidak ada bekas luka pada bagian badannya, gerakannya lincah serta memiliki panjang badan 3,5-6 cm dan telah matang gonad. Induk yang telah diseleksi dan matang gonad memiliki panjang cangkang berkisar 3,0-4,0 cm untuk induk jantan dan $3,6-5,0 \mathrm{~cm}$ untuk induk betina, sedangkan bobot badan rata-rata adalah $46 \mathrm{~g}$ untuk induk jantan dan 53 g untuk induk betina.

Induk betina memiliki panjang cangkang serta bobot badan lebih besar dibanding induk jantan. Perbedaan ukuran serta penurunan tingkat pertumbuhan ini berkaitan dengan pematangan gonad. Di mana induk jantan cenderung memiliki ukuran badan yang lebih kecil bila dibanding dengan induk betina, dikarenakan jantan mengeluarkan lebih banyak energi selama reproduksi dibanding dengan betina (Setyono, 2003). Seleksi induk dengan menggunakan spatula di mana gonad induk jantan berwarna merah muda atau orange kekuningan, sedangkan induk betina berwarna hijau muda (Gambar 2).

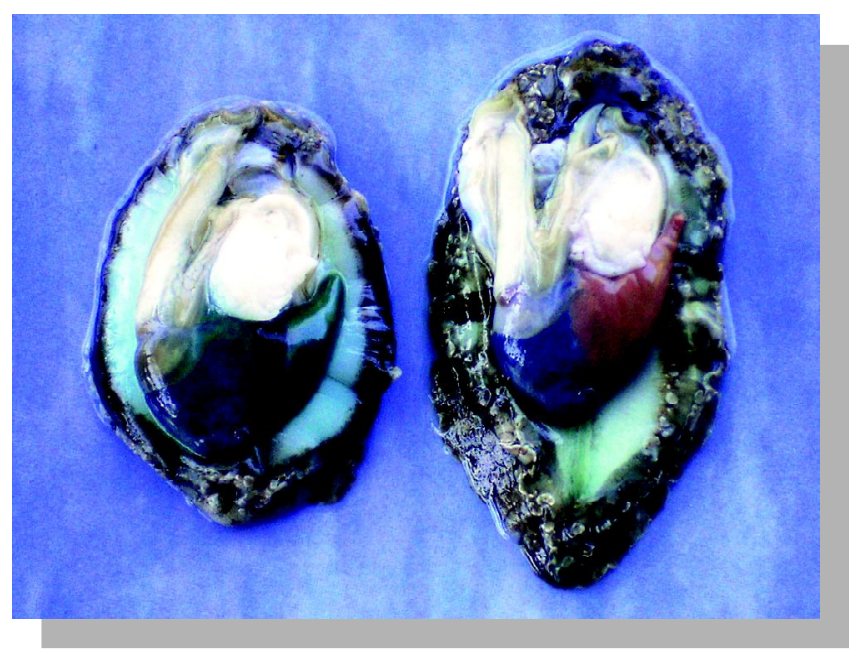

Gambar 2. Perbedaan warna gonad induk jantan dan betina

Induk yang diseleksi telah matang gonad penuh (fully ripe) dengan ciri-ciri gonad menggembung terisi penuh telur dan persentase penutupan gonad terhadap kelenjar pencernaan pada induk yang matang gonad (fully ripe) adalah lebih dari $50 \%$

\section{Penanganan Induk}

Induk alam yang baru datang diaklimatisasi selama kurang lebih 30 menit dan bila kondisi induk telah bergerak lincah dan menggeliatkan badannya menandakan proses aklimatisasi berhasil. Abalon dimasukkan dalam keranjang pemeliharaan induk dengan jumlah 30-35 ekor tiap keranjangnya. Hal ini dimaksudkan agar populasi abalon dalam keranjang tidak terlalu padat yang akan berpengaruh terhadap persaingan makanan, persaingan oksigen, dan juga persaingan substrat penempelan. Setyono (2003) dalam Setyono (2005) menyatakan bahwa kepadatan optimum larva untuk budidaya dengan menggunakan bak di luar ruangan adalah sebanyak 50 ekor yuwana/m²untuk panjang cangkang $<40 \mathrm{~mm}$, sedangkan untuk yuwana dan induk dengan panjang cangkang $>40$ $\mathrm{mm}$ maksimal sebanyak 38 ekor $/ \mathrm{m}^{2}$.

Priyambodo et al. (2005) bahwa pemeliharaan induk terpisah antara jantan dan betina. Induk jantan dan betina dimasukkan dalam keranjang dengan warna yang berbeda (Gambar 3) untuk memudahkan dalam menyeleksi indukinduk matang gonad pada waktu pemijahan.

Induk memerlukan substrat menempel berupa genting ukuran $30 \mathrm{~cm} \times 22 \mathrm{~cm}$ dan potongan pipa PVC ukuran 8 

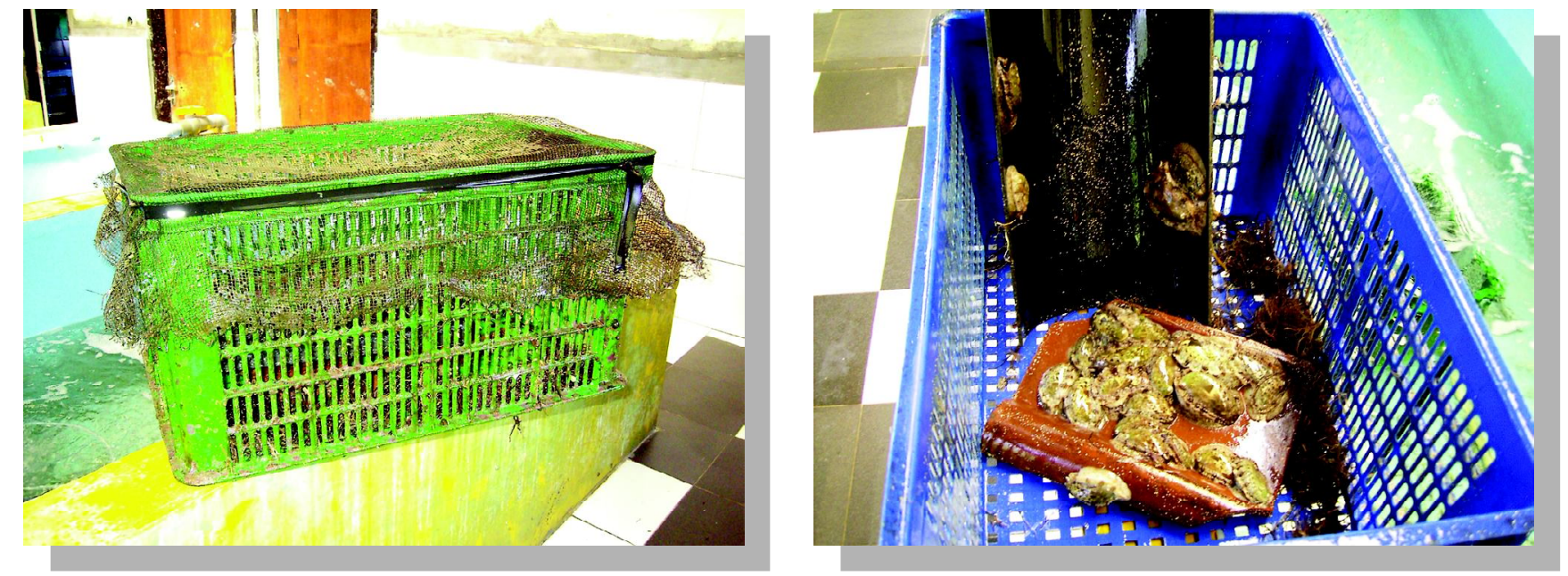

Gambar 3. Keranjang pemeliharaan induk abalon

inci berwarna hitam. Hasil pengamatan menunjukkan bahwa genting lebih disukai sebagai substrat penempelan dibanding dengan potongan pipa PVC. Hal ini dapat dilihat dari persentase penempelan induk pada substrat genting lebih banyak dibandingkan substrat potongan pipa PVC (Gambar 4). Fallu (1991) yang menyatakan bahwa dalam perkembangan budidaya abalon, shelter yang pertama kali digunakan berupa genting. Di mana genting ini diletakkan dalam posisi terbalik yaitu bagian yang terbuka dihadapkan ke dasar/lantai. Pada perkembangan selanjutnya, digunakan shelter dari bahan PVC dengan diameter $20 \mathrm{~cm}$.

Bak yang digunakan untuk pemeliharaan induk adalah bak beton (ukuran $5 \mathrm{~m} \times 1 \mathrm{~m} \times 1 \mathrm{~m}$ ) atau volume $5 \mathrm{~m}^{3}$. Ketinggian air pada setiap bak pemeliharaan induk berkisar 40-50 cm dilengkapi sistem air mengalir (flow through system) sehingga pergantian air dalam bak mencapai $200 \%$

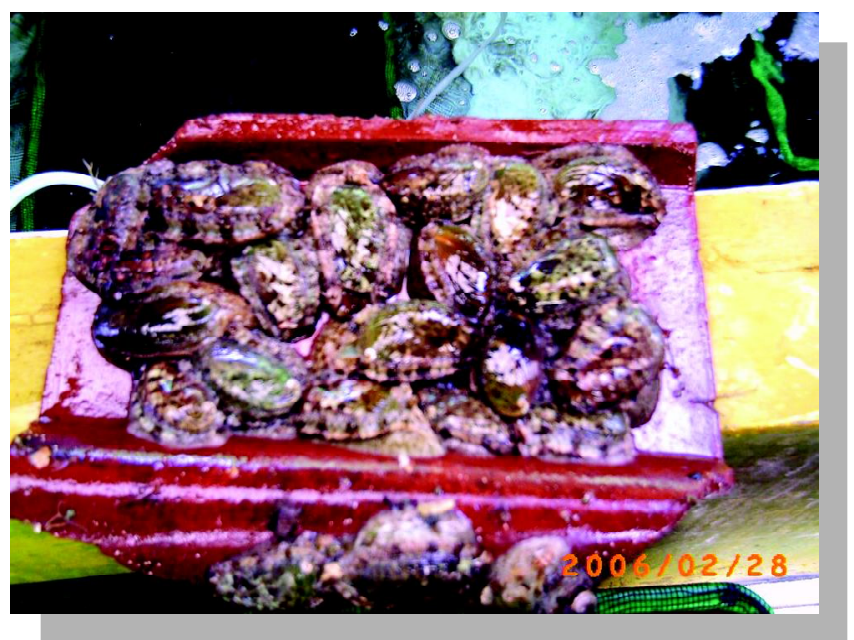

Melalui sistem air mengalir ini diharapkan ketersediaan oksigen selalu terjamin dan kotoran yang mengendap pada dasar bak akan terbawa menuju saluran outlet sehingga kebersihan bak akan tetap terjaga.

Pembersihan bak dilakukan setiap hari atau maksimal dua hari sekali dengan menguras total air dalam bak, menyikat bak serta membersihkan kotoran serta sisa pakan. Stickney (2000) menyatakan bahwa bak pemeliharaan induk harus selalu dibersihkan untuk mencegah pertumbuhan Copepoda, Nematoda serta bakteri lain yang membahayakan. Selain itu, sarana dan prasarana pembenihan perlu dicek agar tidak ada organisme pengganggu yang menempel dan mengganggu sirkulasi air.

\section{Pengelolaan Pakan}

Pakan abalon berupa rumput laut jenis Gracilaria sp. yang didapat dari perairan sekitar Pantai Lombok. Hasil

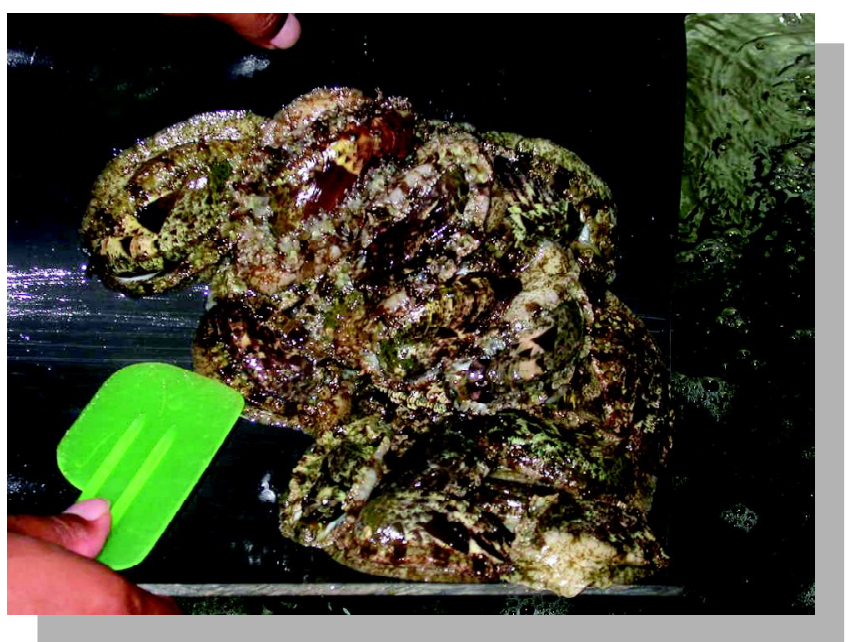

Gambar 4. Penempelan induk abalon pada substrat genting dan potongan pipa PVC 

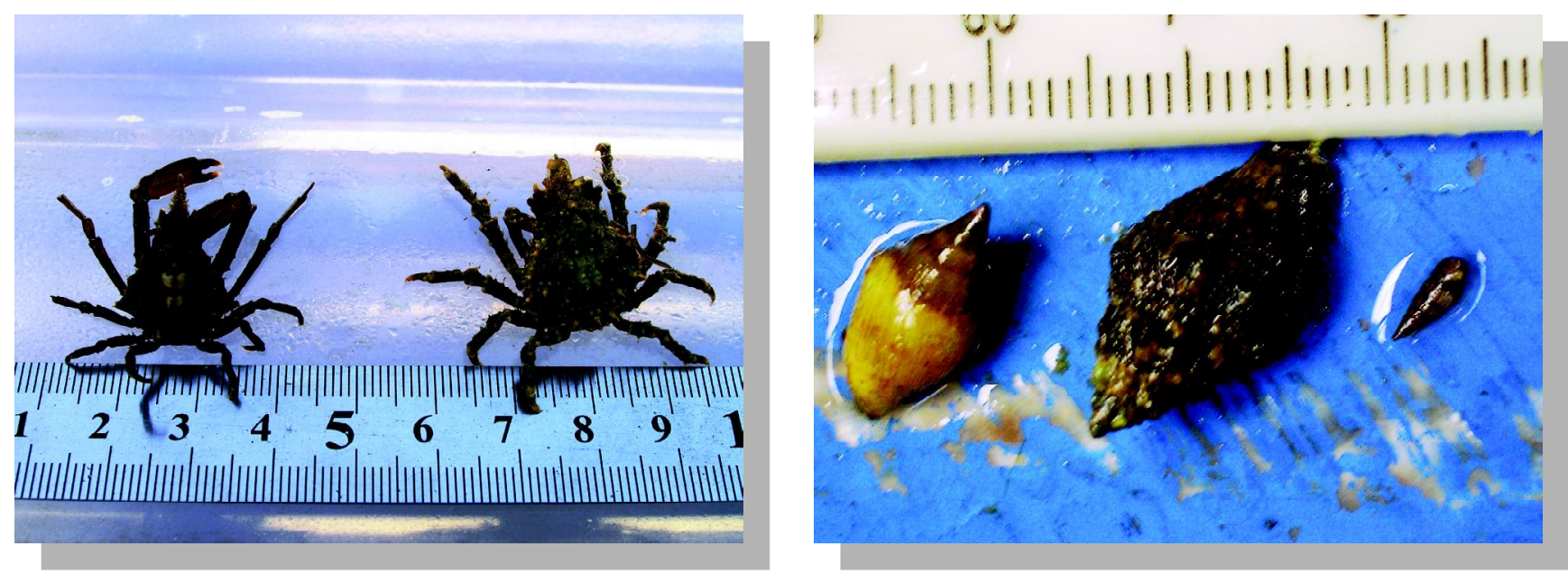

Gambar 5. Kompetitor abalon (kepiting dan teritip)

penelitian Rusdi et al. (2009) bahwa pemberian pakan Gracilaria sp. pada pemeliharaan yuwana abalon dapat memberikan respons positif terhadap pertumbuhan bobot abalon.

Pakan rumput laut jenis Gracilaria sp. sebelum diberikan pada induk abalon dibersihkan terlebih dahulu dari kotoran serta binatang-binatang laut (seperti teritip, kepiting atau bintang laut) yang merupakan kompetitor serta predator bagi abalon (Gambar 5).

\section{Identifikasi Penyakit}

Kematian induk yang sering menjangkit selama pemeliharaan induk abalon (Haliotis asinina) disebabkan oleh dua macam penyakit yaitu penyakit karat dan pembengkakan organ dalam terutama lambung (Gambar 6). Induk yang terjangkit penyakit karat menyebabkan bagian dalam cangkang berwarna coklat seperti karat besi sehingga daging akan terlepas dari cangkang. Penyakit yang disebabkan oleh pembengkakan organ dalam menyebabkan lambung akan menggembung dan hanya berisi udara.

\section{Pengelolaan Air}

Pengelolaan air sebagai media pemeliharaan yang dilakukan dalam pembenihan abalon meliputi pergantian air dan pengamatan parameter kualitas air pada bak pemeliharaan induk serta bak persiapan pakan awal larva. Sistem filterisasi air laut yang digunakan sangat sederhana yaitu menggunakan karang-karang laut (Gambar 7) yang dimasukkan dalam waring ukuran mata jaring $5 \mathrm{~mm}$ (ukuran $120 \mathrm{~cm} \times 30 \mathrm{~cm}$ ). Filter karang diletakkan dalam saluran outlet berukuran $150 \mathrm{~cm} \times 100 \mathrm{~cm} \times 100 \mathrm{~cm}$ dan ditumpuk sehingga menenuhi saluran outlet. Selanjutnya air dialirkan melalui sistem filtrasi berupa filter bag ukuran mata jaring $50 \mu \mathrm{m}$ dan $10 \mu \mathrm{m}$.
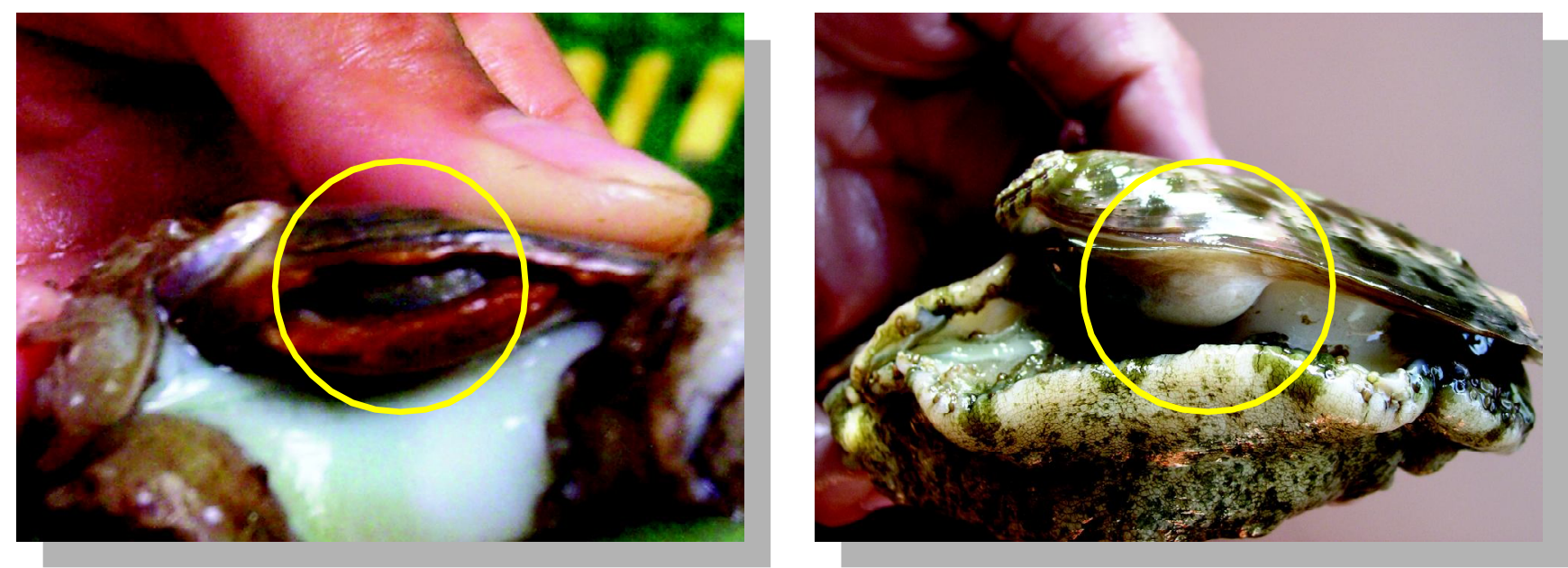

Gambar 6. Penyakit karat dan pembengkakan organ dalam 

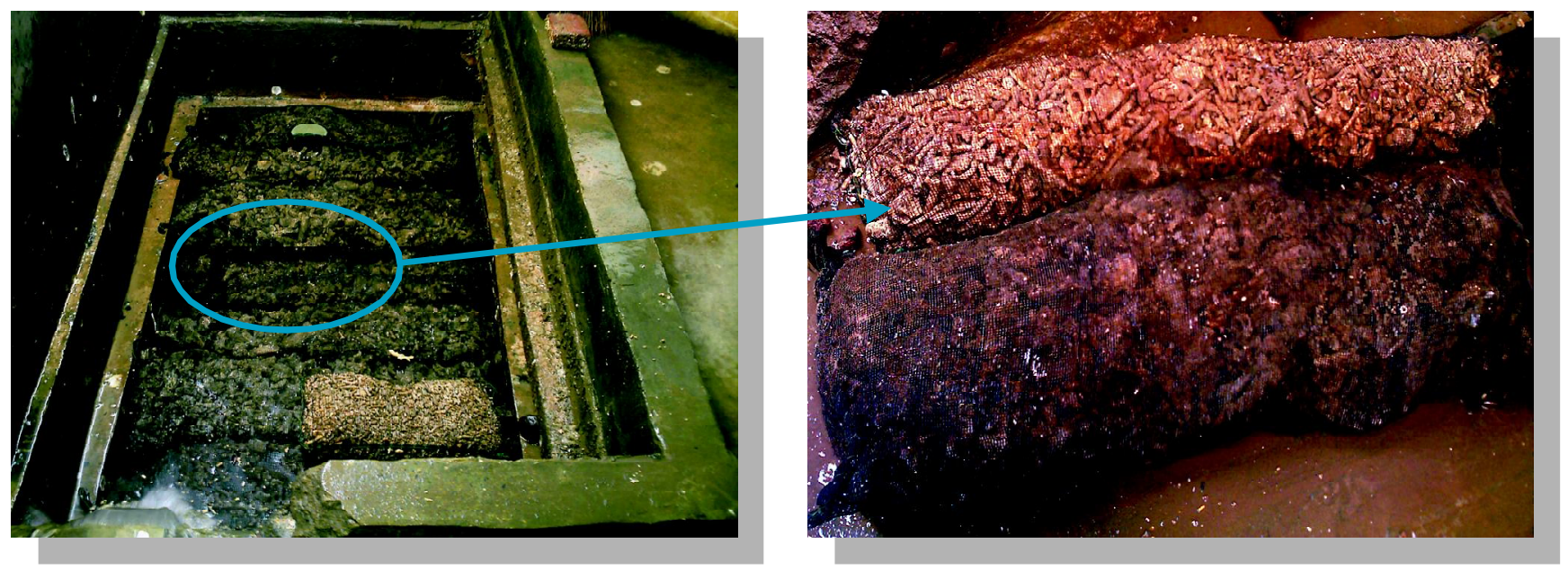

Gambar 7. Filter karang dalam sistem filterisasi

Stickney (2000) yang mengatakan bahwa abalon memerlukan kualitas air yang bagus untuk pertumbuhannya sehingga untuk membudidayakannya dibutuhkan air laut yang bersih.

\section{PENUTUP}

M anajemen pemeliharaan induk abalon hasil tangkapan dari alam yang mengacu pada standar budidaya, meliputi pengumpulan induk, seleksi induk, penanganan induk, pengelolaan pakan dan penyakit, serta pengelolaan air media pemeliharaan. Apabila seluruh aspek tersebut dijalankan sesuai standar dan prosedur yang ditetapkan, diharapkan akan diperoleh induk dengan tingkat produksi yang tinggi dan benih yang berkualitas sehingga dapat mengurangi tingkat eksploitasi penangkapan abalon dari alam.

\section{DAFTAR ACUAN}

Bamfield. 2005. The Amazing Abalon, Haliotis kamtschatkana : Northern (Pinto) Abalon Biology. http:/ /www.abalonlife.net/guide, 1 pp.

Bilowo, S. 1973. Bahan Makanan Dari Laut. Lembaga IImu Pengetahuan Indonesia, Lembaga Oceanologi Nasional. Jakarta, $33 \mathrm{hlm}$.

Ditjenkanbud, 2004. Membangun Kejayaan Perikanan Budidaya. http://www.abalon.net/guide, 1 HLM.

Effendi, H. 2003. Telaah Kualitas Air. Kanisius. Yogyakarta, $257 \mathrm{pp}$.

Fallu, R. 1991. Abalon Farming. Fishing News Book. London, $196 \mathrm{pp}$.

FAO. 2000. Synopsis Of Biological Data On The European Abalon (Ormer) Haliotis tuberculata. FAO Fisheries Synopsis, 156: 22.
Imai, T. 1977. Technique Of Abalon Culture. Aquaculture In Shallow Seas. New Delhi, p. 379-390.

Priyambodo, B., Sofyan, Y., \& Jaya, I.S. 2005. Produksi Benih Kerang Abalon (Haliotis asinina) Di Loka Budidaya Laut Lombok. Seminar Nasional Tahunan Hasil Penelitian Perikanan dan Kelautan. Perikanan dan Kelautan UGM, Yogyakarta, hlm. 144- 148.

Rusdi, I., Susanto, B., \& Rahmawati, R. 2009. Sintasan dan Pertumbuhan Yuwana Abalon, Haliotis diversicolor Asal Pembenihan Dengan Pemberian Jenis Pakan Berbeda. Prosiding Forum Inovasi Teknologi Akuakultur. Jakarta, hlm. 59-64.

Sarifin. 2010. NTB Belum Mampu Penuhi Permintaan Ekspor Abalon. http://www. antaramataram.com/ berita, $1 \mathrm{hlm}$.

Setiawati, K.M., Yunus, Setyadi, I., \& Arfah, R. 1995. Pendugaan Musim Pemijahan Abalon (Haliotis asinina) Di Pantai Kuta, Lombok Tengah. J. Pen. Perik., I(3): 124- 130.

Setyono, D.E.D. 1997. Culture Techniques On The Farming Of Abalon (Haliotis sp.), A Perspective Effort For Aquaculture In Indonesia. Oseana, XXII(I): 1-8. 20-25. . 2003. Abalon Culture. Oseana, XXI(1): 2005. Abalon (Haliotis asinina) : 5. Early Juvenile Rearing And Ongrowing Culture. Oseana, 30(2): 1-10.

2006. Karakteristik Biologi dan Produk Kekerangan Laut. Oseana, XXXI(I): 1-7.

Stickney, R.R. 2000. Abalon Culture. Encyclopedia Of Aquaculture. California, p. 1-6.

Sudradjat, A. 2008. Abalon. Budidaya 23 Komoditas Laut 
Menguntungkan. Penebar Swadaya. Jakarta, hlm. 138138.

Sutarmat, T., Yunus, Yudha, H.T., \& Giri, N.A. 2009. Padat Penebaran dan Ukuran Benih Menentukan
Pertumbuhan dan Sintasan Benih Abalon (Haliotis asinina). Prosiding Forum Inovasi Teknologi Akuakultur. Jakarta, hlm. 27-33. 